\title{
DESIGN OF WEB-BASED INFORMATION SYSTEM ON MONITORING THE WATER QUALITY OF CATFISH POND
}

\author{
Dwi Nugraheni K. ${ }^{1}$, Salma Adiba C. ${ }^{2}$, Eko Supriyanto ${ }^{3}$, and Endro Wasito 4 \\ ${ }^{1}$ D3 Telecommunication Engineering, Semarang State Polytechnic
}

\begin{abstract}
Water environmental factors that greatly affect the survival and growth of catfish include temperature and water $\mathrm{pH}$ with $\mathrm{pH}$ range of $6.5-8$ and temperature of $25^{\circ} \mathrm{C}-30^{\circ} \mathrm{C}$. The monitoring and measurement are still done manually by catfish farmers to get the temperature and $\mathrm{pH}$ parameter values without knowing the exact value of these measurements. According to those problems, this final project provides an information system on monitoring the water quality of catfish pond to facilitate monitoring, namely by using a device that is remotely controlled in real-time, and contains sensors needed for measurement so that it can measure the parameters from a different place. Each node in each pond contains a measurement system using a DS18B20 temperature sensor and a SEN0161 $\mathrm{pH}$ sensor that can measure temperature and $\mathrm{pH}$. The system is using a method with several stages, namely the stages of design, implementation and testing. The measurement results from the temperature sensor and $\mathrm{pH}$ sensor are displayed on the web page in the form of graphs and tables.

Index Terms-: Monitoring, DS18B20 sensor, sen0161 pH sensor, real-time.
\end{abstract}

\section{Introduction}

Water environmental factors that greatly affect the survival and growth of catfish include temperature, acidity $(\mathrm{pH})$, ammonia levels, and the degree of turbidity of water in catfish pond. The metabolism that takes place in the body of the catfish is very dependent on the temperature of the water. The temperature range that can be tolerated by catfish is $25^{\circ} \mathrm{C}-30^{\circ} \mathrm{C}$. Whereas the recommended $\mathrm{pH}$ value in the pond is maintained at 6.5-8 [1].

The monitoring and measurement are quite easy to do, just by taking litmus paper to the location, taking measurements, and getting results from the monitoring and measurement. The data obtained is then analyzed to get information that will be useful for making decisions about a situation. However, the monitoring must be carried out repeatedly every day while human resources are limited, and there are still many other responsibilities besides monitoring, then this can be a significant obstacle. The lack of this observation method resulted in the pond farmer that experiencing delays in handling the bad conditions of the pond water environment which resulted in a deficient quality of catfish and even can cause death in catfish.

According to those problems, this final project provides an information system to monitor the water quality of catfish pond by using a remotely controlled device containing a DS18B20 temperature sensor and sen0161 pH sensor.

\section{Basic Theory}

A. Wireless Communications

Wireless communication is the transfer of information between one point to another point that is not connected by inductor wire / conductor. Wireless communication can be done through [2]:

1. Radio frequency communication.

2. Microwave communication, for example long line-ofsight through highly directional antennas, or shortrange communication.

3. Infrared (IR) short distance communication, for example from a remote control or through the Infrared Data Association (IrDA).

4. Application may involve point-to-point or point-tomultipoint communication, broadcasting, cellular networks and other wireless networks.

\section{B. Arduino Uno}

Arduino can be said to be a platform of physical computing (a device which uses interactive software and hardware) that is open source. The software used on Arduino is an IDE (Integrated Development Environment). In this study, Arduino is used to process data from $\mathrm{pH}$ sensor and temperature sensor as well as display the results of monitoring on a laptop [3]. The shape of the Arduino Uno device can be seen in Figure 1.

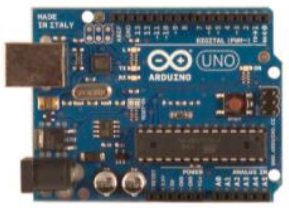

Figure 1 Arduino Uno

\section{ESP 8266 Module}

ESP8266 module is a connected-chip component 
designed for the needs of today's connected world. This chip offers Wi-fi networking, a complete and integrated solution, which can be used as an application provider or to separate all functions from Wi-fi networking to the other application processors. ESP8266 has the features of on-board processing and storage that allows the chip to be integrated with sensors or certain tool applications through the output input pin only with short programming [4]. ESP8266 module is shown in Figure 2.2

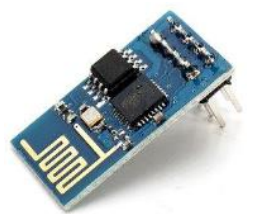

Figure 2 ESP 8266 Module

\section{DS18B20 Temperature Sensor}

DS18B20 temperature sensor is a temperature sensor with the feature of waterproof making it suitable for measuring temperatures in distant or wet places. The output of DS18B20 temperature sensor is digital data. In this study, the temperature sensor is used as a sensor to detect the temperature in catfish pond [5]. Figure 2.3 is a picture of a temperature sensor

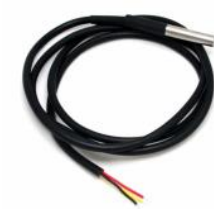

Figure 3 DS18B20 temperature sensor

\section{E. SEN0161 pH Sensor}

SEN0161 pH sensor is a tool used to measure or determine the acidity level of a solution in broad outline. This tool can measure $\mathrm{pH}$ between 0 to 14 . In this study, SEN0161 pH sensor is used as a sensor to detect $\mathrm{pH}$ in catfish pond [6]. Figure 2.4 is a picture of SEN0161 pH sensor.

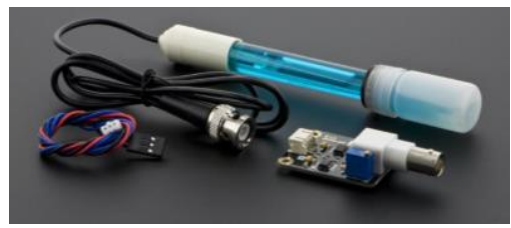

Figure 4 pH sensor sen0161

\section{F. HTML}

HTML stands for Hypertext Markup Language, a text file written using certain code rules to be presented to users through web browser application. HTML is in the form of tag codes that instruct the browser to produce the display as intended. An HTML file can be opened with a web browser such as Mozilla Firefox, Microsoft Internet

\section{Explorer or Chrome [7]. \\ G. MySQL Basic Data}

MySQL is a database management system software that is very popular among programming web, especially in Linux environments using scripts of PHP and Perl (Sonty Lena \& Mochamad Ridwan, 2014). Software database is now also available on platform of Windows operating system. Each user can freely use $M y S Q L$, but with the limitation of the software may not be used as a derivative product that is commercial. MySQL is a derivative of one of the main concepts in existing databases; $S Q L$ (Structured Query Language). SQL is a concept of operating the database, especially for selecting and entering data, which allows the operation of data can be easily processed automatically [8]. Figure 5 is a display from the MySQL database.

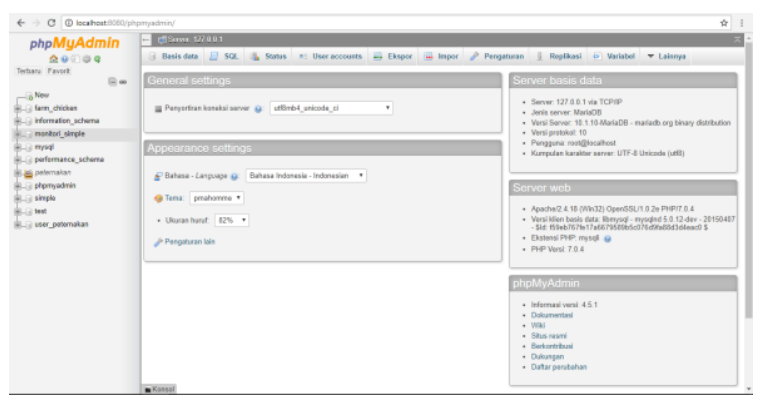

Figure 5 MySQLDatabase

\section{H. PHP}

Hypertext Preprocessor or commonly known as PHP is one of programming languages that works on a web server and is a data processor from a server. PHP is integrated with HTML on the server. All scripts that use the PHP programming language will be executed on the server where the script is run [9].

\section{CodeIgniter Framework (CI)}

Framework can be interpreted as a tool used to help work. Within the scope of website making, the framework can be interpreted as a tool that can be used to facilitate website making. Framework is a collection of third party components that are combined into one. This causes workwith-website using the framework to be faster and easier (Putra, 2017).

CodeIgniter is a PHP framework that is open source and uses the MVC (Model View Control)-based model, which is a modern concept model of the framework used nowadays. With this MVC concept, all kinds of logic and layout have been separated, so the programmer and designer can accomplish each task in focus. The concept of the MVC model can also guide program makers to build the web in a structured way [10].

J. Black-box Testing Method 
Software testing techniques are grouped in either white or black-box testing. Black-box focuses on the functional requirements of a software. Testing with the method of black-box focuses on the output generated from the selected response of input. Black-box testing is done based on software requirements specifications without checking the coding of the information system. The importance of testing with this method is to help the overall system function validation process. This testing is carried out based on the end user perspective which handles valid and invalid input from the customer's perspective [11].

\section{K. Use Case}

Use case is a technique used in software development or information systems to help meet the system's functional needs. Use case is interaction between system and actor, including message exchanges, actions taken by the system and providing measurable results to user or external system. Use case has an object called a scenario that states the order of the message and one action [12]

\section{ERD}

Entity Relationship Diagram is a diagram or model of data presentation that contain components of entities and relationships, each of which is equipped with attributes that describe the logical structure of the graphical database. The use of ERD aims to make the database easier to understand and also facilitate database design [13].

Cardinality Relationship Mapping is a description of the maximum number of entities that can relate to an entity in a collection of other entities. Especially for the set of binary relations, cardinality mapping can be one of the following types:

1) One to One

An entity can only relate to one object in another entity. This cardinality is symbolized by $1-1$.

2) One to Many

An entity can relate to many objects in another entity. This cardinality is symbolized by $1-\mathrm{m}$.

3) Many to One

Many entities are related to the same object in another entity. This cardinality is symbolized by $\mathrm{m}-1$.

4) Many to Many

Many entities are related to many objects in other entities. This cardinality is symbolized by $\mathrm{m}-\mathrm{n}$.

\section{Flow Chart}

Flow chart is a method used to describe the flow process of an operation. This diagram is possible to apply to computers that use low-level languages such as assemblers and high-level languages such as C, Pascal, and others [14].

\section{Research Method}

Design of Web-based Information System on Monitoring Water Quality of Catfish Pond is done as follows:

1. Observation Method

Observation method is carried out by research and observation of the activities of the farmer in producing catfish.

2. Literature Study Method

Literature study method is a media for collecting the data by searching the literature used in the form of books, articles both from the internet and journals related to the making of Design of Web-based Information System on Monitoring the Water Quality of Catfish Pond.

3. System Development Method

This method is used to determine the design of the system, tools and what materials are needed

The system design is carried out as follows:

a. Designing a database

b. Designing a layout web for the page of login

c. Designing a layout web for page of admin and client

d. Designing features that will be used in this system.

4. Testing Method and Analysis of Testing Results

This testing method is carried out using the black-box method that focuses on functional requirements. Analysis of testing results is the final stage of activities that explain the system that has been made, on how the system is tested and the information obtained after testing.

5. Making a Report

Making a report is done after all stages have been completed so that the results obtained from the making of the system can be explained in detail according to the data obtained.

\section{Result and Discussion}

The system that has been made is an information system for monitoring catfish ponds which contain graphs and tables of temperature and $\mathrm{pH}$ sensor readings. All information will be displayed on the web with the following system architecture.

Figure 6 is a picture of a system for monitoring the temperature and $\mathrm{pH}$ in a catfish pond. The sensor readings will be stored in the information system database on monitoring the catfish pond which will then be displayed through the monitoring website. 

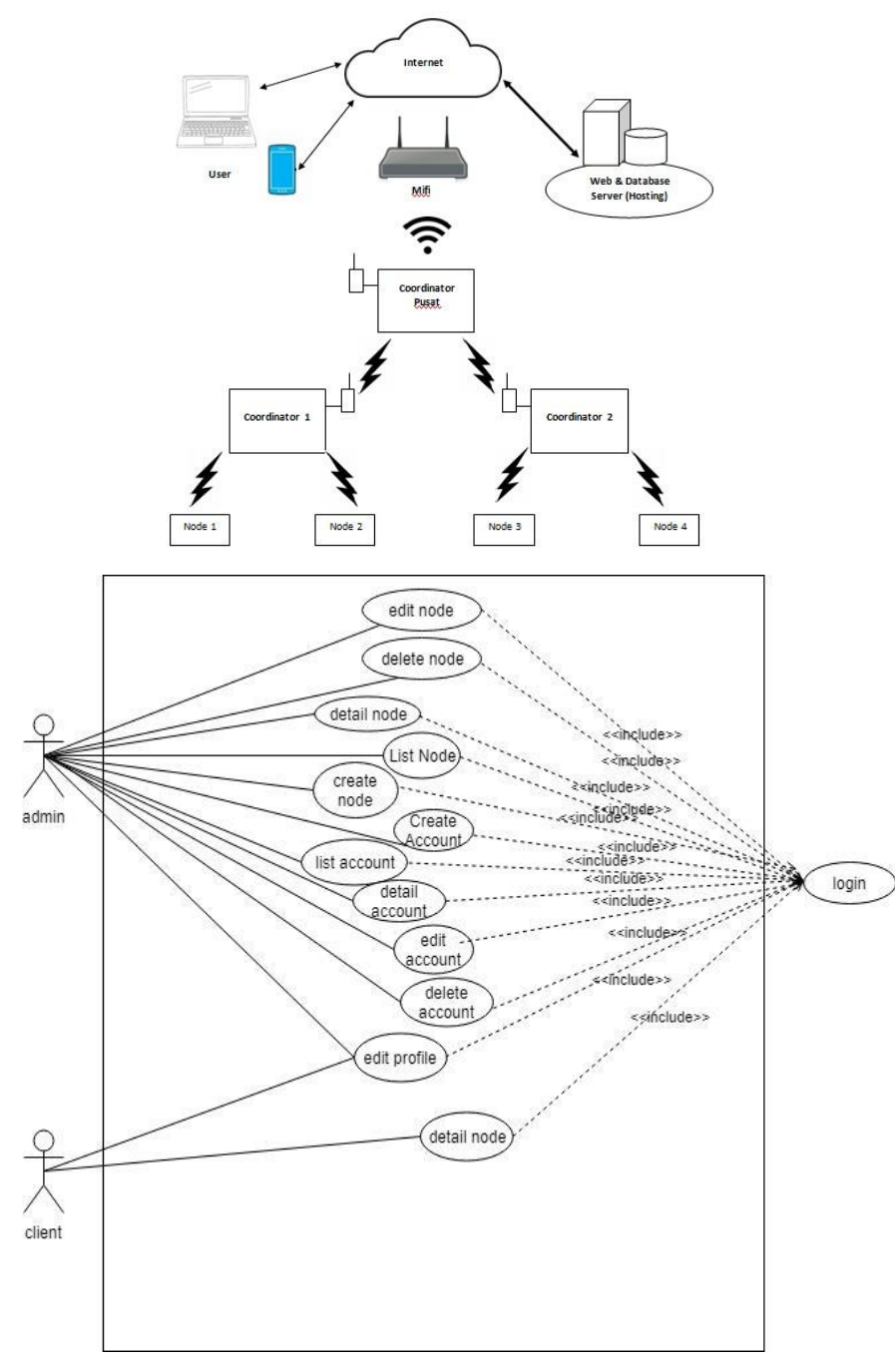

Figure 7 Use Case Diagram

In short, the user level can be understood using the use of case diagram. This diagram will provide a brief overview of the user level and what functions can be performed in the system.

Based on Figure 7, the information system on monitoring the water quality of catfish pond can be accessed by 2 groups, i.e. admin and client. Admin is someone who is the administrator of this monitoring system, while the client is someone who is a customer who uses this monitoring system.

Admin has full access to all data access in the monitoring system. This is because the admin has the highest power as the maker, modifier and remover of all data. Whereas the client has access rights which are limited to seeing the details of the node that displays temperature and $\mathrm{pH}$ information in the form of graphs and tables and also limited to editing profiles.

The information system on monitoring the water quality of the catfish pond has two main pages, namely the admin page and the client page. At first, login process must be done to access the main page either admin or client.

In making database design, ERD is needed to find out
Figure 6 Monitoring System Design

related data in a database. Figure 8 is the ERD from the information system on monitoring the quality of pond water. ERD is also used to provide an overview of the relationship in the database, either the relationships from one to many or many to many. One to many means one data that is inputted in a field, can have more than one relationship with the data that is in another field. While many to many means one data in a field can have and is owned by a data in another field.

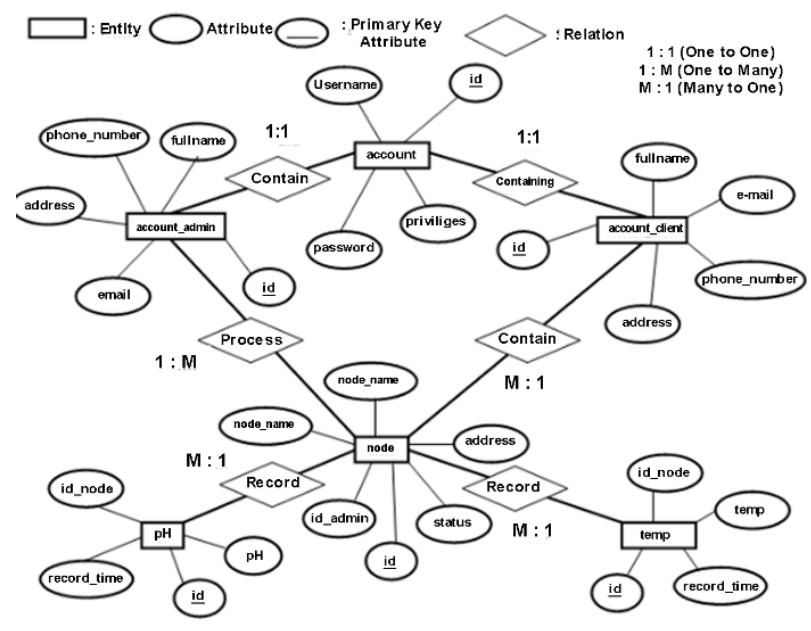

Figure 8 Entity Relationship Diagram

Testing results from the information system on monitoring the water quality of catfish pond are shown in table 1.

Table 1 Results of Testing Functionality

\begin{tabular}{|c|c|c|c|}
\hline No. & Testing & Purpose & Result \\
\hline 1. & Login & $\begin{array}{l}\text { If the username and } \\
\text { password are entered } \\
\text { according to the data } \\
\text { in the database, the } \\
\text { login is successful. If } \\
\text { the data entered does } \\
\text { not match or is not in } \\
\text { the database, an error } \\
\text { warning will appear. }\end{array}$ & Succeed \\
\hline
\end{tabular}




\begin{tabular}{|c|c|c|c|c|c|c|c|}
\hline 2. & Logout & $\begin{array}{l}\text { If the button of } \\
\text { logout works, then it } \\
\text { enters the login page } \\
\text { and session login } \\
\text { ends }\end{array}$ & Succeed & 5. & Add node/device & $\begin{array}{l}\text { Data added is entered } \\
\text { into the database and } \\
\text { is used for storing } \\
\text { temperature and } \mathrm{pH} \\
\text { data }\end{array}$ & Succeed \\
\hline 3. & Add client & $\begin{array}{l}\text { Data that is registered } \\
\text { to the database and } \\
\text { used for } \log \text { in. }\end{array}$ & Succeed & 6. & $\begin{array}{l}\text { Change device } \\
\text { information }\end{array}$ & $\begin{array}{l}\text { Updated data is } \\
\text { stored in the database }\end{array}$ & Succeed \\
\hline 4. & $\begin{array}{l}\text { Client data } \\
\text { update }\end{array}$ & $\begin{array}{l}\text { Data that has been } \\
\text { updated is stored in } \\
\text { the database }\end{array}$ & Succeed & 7. & $\begin{array}{l}\text { Delete node / } \\
\text { device }\end{array}$ & $\begin{array}{l}\text { Deleted node is not } \\
\text { stored in the database }\end{array}$ & Succeed \\
\hline
\end{tabular}

1. The making of information system used MySQL databases to simplify data management and be tested with the method of black-box to prove all features can work as their functions.

2. The information system is made in the form of a website and integrated with the database, so that data processing on information system of the water quality of catfish pond can be processed and stored automatically in the database.

Continued Table 1

\begin{tabular}{clll} 
No. & Testing & Purpose & Result \\
\hline 8. & $\begin{array}{l}\text { Download } \\
\text { file of } \\
\text { monitoring } \\
\text { info recap }\end{array}$ & $\begin{array}{l}\text { Data successfully } \\
\text { downloaded }\end{array}$ & Succeed \\
9. & $\begin{array}{l}\text { Update } \\
\text { profile }\end{array}$ & $\begin{array}{l}\text { User data change } \\
\text { according to the data } \\
\text { inputted }\end{array}$ & Succeed \\
10. & Delete client & $\begin{array}{l}\text { Client / customer that } \\
\text { was deleted is not } \\
\text { stored in the database }\end{array}$ & Succeed \\
11. & $\begin{array}{l}\text { View temperature } \\
\text { and pH }\end{array}$ & $\begin{array}{l}\text { Display temperature } \\
\text { and pH graph }\end{array}$ & Succeed \\
12. & Download graph & $\begin{array}{l}\text { Data successfully } \\
\text { downloaded }\end{array}$ & Succeed \\
\hline
\end{tabular}

3. With the information system on monitoring the water quality of catfish pond, it can facilitate the pond staff on monitoring the temperature and $\mathrm{pH}$ of the pond water every day without having to come directly to the pond location.

4. With this information system on monitoring water quality of catfish pond, it will be easier for workers or pond owner to act when the temperature and $\mathrm{pH}$ are in a bad status which will have an impact on the development of catfish.

5. The information system on monitoring the water quality of catfish pond that is made can run well and answer the problem in this final project on how it can monitor the temperature and $\mathrm{pH}$ of catfish pond in the form of graphs and tables.

\section{B. Recommendation}

Notifications on this monitoring system still have weaknesses, namely notifications that enter email are still in the form of spam. In the future this system is expected to be developed again so that it is more optimal.

Table 1 is the result of black-box testing. According to the table, it can be seen that the information system on monitoring the water quality of catfish pond functionally can produce the results as expected. This information system has an important role in the process of monitoring catfish water pond.

\section{Conclusion and Recommendation}

\section{References}

[1] AN Qomariyah, "Internet Usage Behavior among Adolescents in Cities," Airlangga University Surabaya, 2013.

[2] J. Hartono, Analysis and Design of Information Systems. Yogyakarta: Andi Offset, 2015.

[3] D. Puspitaningsih, "Information System for Dream and Recitation Agenda on Muhammadiyah Regional Leadership in Central Java Based on Website," Dian Nuswantoro University, 2017.

[4] MK Pandit, "Location-based Steganography Implementation on Mobile Smartphones using Android Platform, " Int. J. Comput. Sci. Inf. Technol., vol. 6, no. 3, 2015.

\section{A. Conclusion}

Some conclusions that can be drawn from the overall results of the information system testing in this monitoring system are

[5] DSA Putra, "Web-Based Special Job Development (BKK) Information Development with PH.

[6] Muslikhah, Siti \& Triana Budi W. 2015. Design of Shrimp Pond Water Temperature and PH Monitoring System with Wireless Sensor Network. Final Project. Not published. Electrical engineering major. Semarang State Polytechnic: 
Semarang

[7] Kuncoro , Rudi Banu. 2012. "Website Development of New Nglepen Dome House Tourism Site "in the Journal of Speed Journal - Indonesian Journal on Computer Science. Vol 10 No 2. August 2012.

[8] Causa Prima Wijaya, Kodrat Iman Satoto, dan R. Rizal Isnanto. (2013). Information System Design for Web-based Travel Ticket Booking. Journal of Transmission 15, (2), 2013, 80.

[9] Causa Prima Wijaya, Kodrat Iman Satoto, dan R. Rizal Isnanto. (2013). Information System Design for Web-based Travel Ticket Booking. Journal of Transmission 15, (2), 2013, 80.

[10] Putra, D. S. A. (2017). "Web-Based Special Work Development (BKK) with PHP and MySql at Wonogiri
Vocational School." Yogyakarta State University, 1119.Retrievedfrom http://eprints.uny.ac.id/48093/.

[11] Nidhra, S., \& Dondeti, J. (2012). Black Box and White Box Testing Techniques - A Literature Review. International Journal of Embedded Systems and Applications, 2(2), 29-50. https://doi.org/10.5121/ijesa.2012.2204

[12] Sholeh, Nadiyatul Azizah. 2018. Information System Design for Semarang State Polytechnic Technical Study Program MST. Final Project. Not published. Electrical Engineering Major. Semarang State Polytechnic: Semarang.

[13] A. Kusyanti, M. Data, and S. W. Agung, Modul Brawijaya University - Entity Relasionsip Diagram (ERD). 2011.

[14] I. Setiawan, Programmable Logic Controller dan Teknik Perancangan Sistem Kontrol. Yogyakarta: Andi, 2006. 